\title{
History of the Collegium Internationale Allergologicum: A Very Special Society Devoted to Allergy and Immunology
}

\author{
Johannes Ring ${ }^{a}$ Gianni Marone $e^{b, c, d}$ \\ aDepartment of Dermatology and Allergology, Technical University Munich, Munich, Germany; ${ }^{b}$ Department of \\ Translational Medical Sciences and Center for Basic and Clinical Immunology Research (CISI), University of

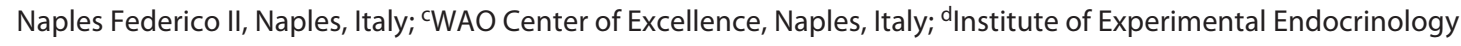 \\ and Oncology "G. Salvatore," National Research Council, Naples, Italy
}

\section{Keywords \\ Collegium Internationale allergologicum · History · \\ Symposia $\cdot$ Allergy $\cdot$ Immunology}

\begin{abstract}
The Collegium Internationale Allergologicum (CIA) was founded on 15 October 1954 in London by a group of 48 international allergists and immunologists from 18 countries of all continents, among them such distinguished scientists as Carl Prausnitz-Giles, Sir Henry Dale, Paul Kallos, and many others. Contrary to other international associations in the field, this Collegium limited the number of members in order to allow more intense and open discussions in "the humble spirit of scientific enquiry, friendly cooperation, good fellowship and professional relationships in the field of allergy" as stated in the statutes. It is not possible to apply for membership, and one has to be proposed by at least 2 CIA members and invited to present at least once at a symposium. Over the decades, a rhythm of biannual symposia developed, the 32nd held in Palma de Mallorca in October 2018. These symposia went around the world from London, Rome, Copenhagen, New Orleans, Puerto Vallarta, Nantucket, Hakone, Konstanz, Goeteborg, and Sorrento, just to name a few places.
\end{abstract}

Preferably they were held on islands such as Capri, Corfu, Martinique, Curacao, Bornholm, Malta, and Ischia in order to make it more difficult for people to arrive late or leave early. It is expected that participants stay over the whole length of the 5-day symposium. On these symposia, it is good custom to also present unpublished data, so participants get the latest news. The most important developments in the field of Allergy and Clinical Immunology have been discussed at early stage and sometimes by speakers who later won the Nobel Prize. While all presentations are equal, be it oral communications or posters, there are 3 special lectures, namely the Carl Prausnitz lecture, the Paul Kallos lecture, and a "Relaxing from Immunology" lecture which can be devoted to any interesting topic not necessarily related to medicine or allergy. Since many years, the contents of the symposium are published in a proceedings volume, over a longtime printed within the "International Archives of Allergy and Immunology" which until now is the official journal of the Collegium. Participants agree that in the flood of more and more scientific congresses and larger events, the CIA Symposia are unique in their openness and friendly scientific interchange.

(c) 2021 S. Karger AG, Basel

Edited by: H.-U. Simon, Bern. karger@karger.com www.karger.com/iaa

Karger
(C) 2021 S. Karger AG, Basel

C.2021 S. Karger AG, Basel.
Correspondence to:

Johannes Ring, johannes.ring@tum.de 


\section{Introduction}

In the early 50s of the last century, allergy and immunology were not among the first disciplines to be recognized and academically established strongly within European and North American Universities, partly due to the interdisciplinary character of these fields. There was a trend to form national and international societies under various names like "Allergy," "Allergology," "Allergy and Clinical Immunology," "Allergy and Immunity Research," or others. In 1951, the "International Association of Allergy and Clinical Immunology" was founded, followed by the "European Academy of Allergology and Clinical Immunology" [1].

There was a feeling that in between these rather large societies it would be good to have a smaller group, allowing more intense contact and discussions between the leaders in the field. So on October 15, 1954, the Collegium Internationale Allergologicum - soon known under the acronym of "CIA" - was founded in the city of London by 48 well-known clinical investigators and basic immunologists from 18 countries of all continents and from very different fields of medicine and biological research. The majority was Anglo-Saxon with 10 scientists from United Kingdom, 7 from USA, and 3 from Australia (Table 1) [2].

\section{Statutes and Leadership}

The statutes clearly define the aims of this association with the simple sentence. "the Collegium is an international group for study of scientific and clinical problems in allergy and related branches of medicine and immunology. The collegiums aims to promote the humble spirit of scientific enquiry, friendly cooperation, good fellowship and professional relationships in the field of allergy."

Not fortuitous was it that the acronym "CIA" alluded to a somehow exclusive character of this club of friends. From the beginning, membership was originally limited to maximum of 100 living members and since 1986 to 250 active members.

Nobody can apply for membership. New members only can be introduced by invitation through a CIA member; before they will be selected, he or she has to present original research work at one symposium as active participant. The Collegium is governed by a Council of 8 members and the officers including the president, the past president, the vice president, and the secretary.
Table 1. Founder members of the Collegium Internationale Allergologicum in October 1954 in London
O.G. Bier (São Paulo)

P. Blamoutier (Paris)

D. Bovet (Rome)

C.J.C. Britton (London)

H. Christensen (Roskilde)

R.R.A. Coombs (Cambridge)

Sir H.H. Dale (London)

H.A.E. van Dishoeck (Leiden)

R.H.O. Donald (Melbourne)

J. Duchaine (Bruxelles)

J. Freemann (London)

C. Frugoni (Rome)

C.P. Giles (Ventnor, GB)

F. Gross (Basel)

M.T. Gutman (Jerusalem)

K. Hansen (Lübeck)

D. Harley (London)

C. Jimenez-Diaz (Madrid)

E.A. Kabat (New York)

P. Kallós (Helsingborg)

L. Kallós-Deffner (Helsingborg)

W. Kaufman (Bridgeport,

Connecticut)

A. Lunedei (Firenze)

W. Löffler (Zürich)

M. Maekawa (Kyoto)

J.R. Marrack (Cambridge)

R.L. Mayer (Summit, NJ)
R. Meier (Basel)

G. Melli (Milano)

G. Miescher (Zürich)

H.R. Olivier (Paris)

D. Ordman (Johannisburg)

Z. Ovary (Rome)

W. Pagel (London)

G.W. Pickering (London)

S. Raffel (Stanford, CA)

Bret Ratner (New York)

B.M.B. Riley (Sydney)

C. Rimington (London)

E. Rothlin (Basel)

H. Selye (Montreal)

U. Serafini (Rome)

M.A. Solari (Buenos Aires)

R.S. Steel (Sydney)

A. Stoll (Basel)

G.L. Waldbott (Detroit,

Michigan)

J. Waldenstroem (Malmö)

F.F. Yonkman (Summit, NJ)
The first president was D. Harley from London, with Vice president J. Duchaine from Brussels. The secretary was Paul Kallos from Helsingborg who did most of the organizational work in the first decades.

For many decades (1980-2010), 2 eminent scientists, Alain de Weck in Europe and Lawrence M. Lichtenstein in the USA (Fig. 1,2), played a semiformal but substantial role in recruiting new members from different countries and in supporting the organization of several biannual meetings. The Alain de Weck travel grant program to support young fellows, named after him, has been established to recognize his dedication to the Collegium. The most important activity of the Collegium is the organization of a scientific meeting in a biannual rhythm on very special places going around the world.

The last 32nd symposium has held in Palma de Mallorca in October 2018. The 33rd symposium should take place in September 2020 in Montebello, ON (Canada). Unfortunately, due to the COVID-19 pandemic, the symposium has been postponed to 2021 . 
Table 2. Officers of the CIA

\begin{tabular}{ll}
\hline President & \\
D. Harley & $1954-1974$ \\
G.B. West & $1974-1978$ \\
F. Milgrom & $1978-1982$ \\
K. Ishizaka & $1982-1986$ \\
A. Sehon & $1986-1990$ \\
A. de Weck & $1990-1994$ \\
L. Lichtenstein & $1994-1998$ \\
J. Bienenstock & $1998-2002$ \\
J. Ring & $2002-2006$ \\
G. Marone & $2006-2010$ \\
S. Galli & $2010-2014$ \\
S. Holgate & $2014-2018$ \\
B. Bochner & $2018-$ \\
\hline Honorary secretary & \\
P. Kallos & $1954-1974$ \\
A. de Weck & $1974-1986$ \\
A. Capron & $1986-1990$ \\
J. Ring & $1990-1998$ \\
\hline Executive secretary & \\
A. Cerletti & $1954-1974$ \\
P. Dukor & $1974-1988$ \\
J. Bienenstock & $1988-1994$ \\
\hline Secretary general & \\
G. Marone & $1998-2002$ \\
S. Galli & $2002-2006$ \\
S. Holgate & $2006-2010$ \\
B. Bochner & $2010-2014$ \\
T. Bieber & $2014-2018$ \\
D. Vercelli & $2018-$ \\
\hline
\end{tabular}

CIA, Collegium Internationale Allergologicum.

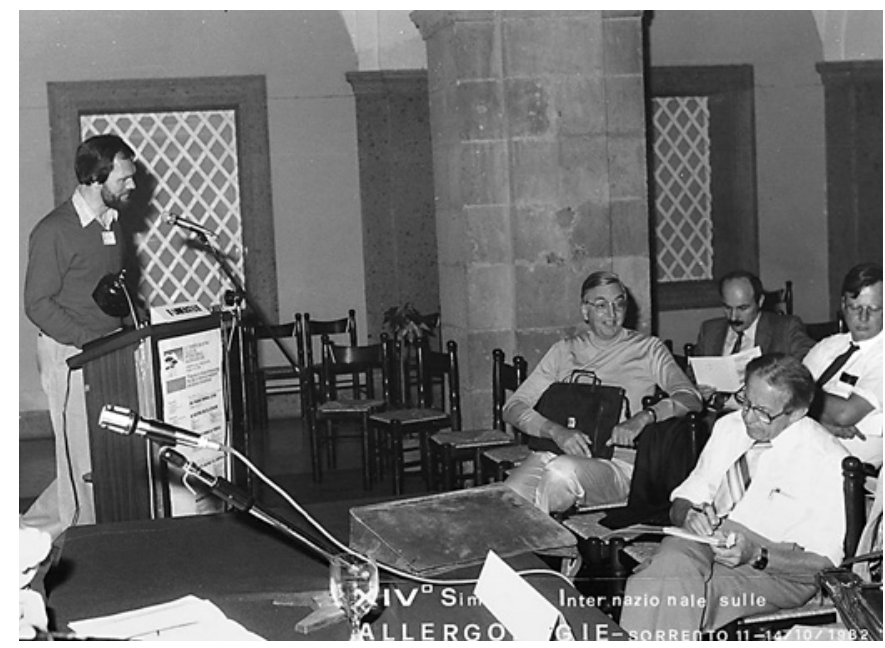

Fig. 1. Henning Löwenstein, Alain de Weck, and Alec Sehon in Sorrento 1982.

History of the CIA

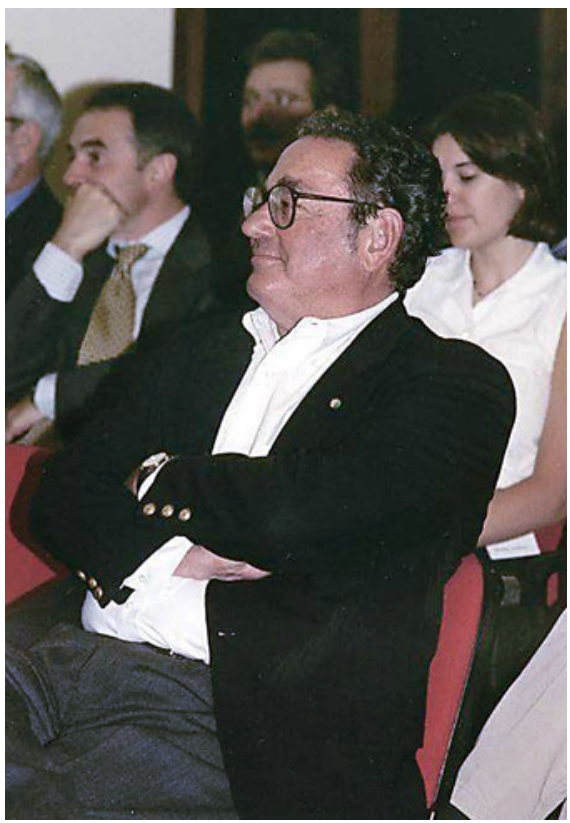

Fig. 2. Lawrence M. Lichtenstein.

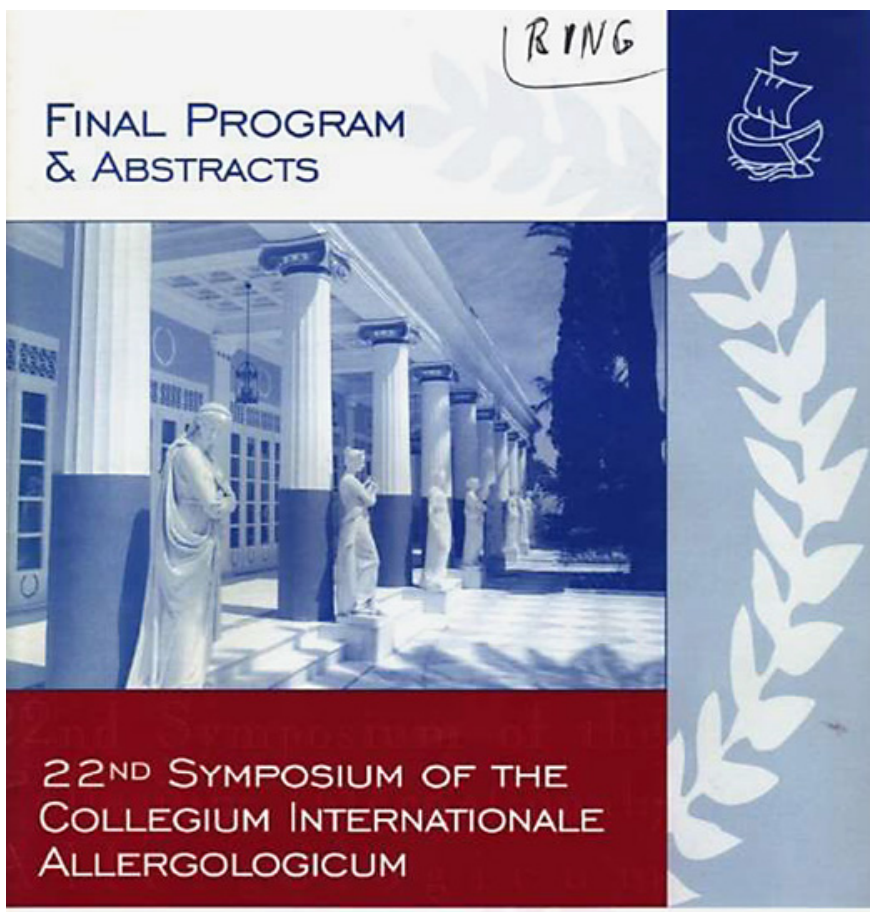

\section{1-16 SEPTEMBER 1998 \\ CORFU of HELLAS}

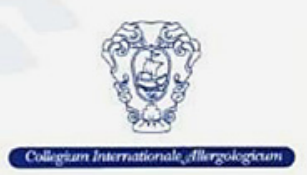

Fig. 3. Cover page of the symposium in Korfu 1998 organized by A. Togias and L.M. Lichtenstein.

Int Arch Allergy Immunol 2021;182:895-903 DOI: $10.1159 / 000515927$ 
Table 3. CIA council members

1954-1955

Duchaine, Coombs, Giles, Kaufman, van Dishoek, Blamoutier, Gutman, Serafini

1955-1957

Van Dishoek, Olivier, Jimenez-Diaz, Kaufman, Coombs, Gross, Waldbott, Hansen

1957-1959

van Dishoek, Coombs, Hansen, Jimenez-Diaz, Feldberg, Hoigné, Olivier, Kaufman

1959-1962

Coombs, Kaufman, Olivier, Gell, Waldbott, Hoigné

1962-1964

Gell, Kaufman, Olivier, Waldbott, Hahn, West, Jaques, Panzani

1964-1968

Hahn, West, Jaques, Panzani, Coombs, Loveless, Sicuteri, White

1968-1970

Coombs, Loveless, Sicuteri, White, Glynn, Glazer, de Weck, Turk

1970-1972

Glynn, Glazer, de Weck, Turk, Feinberg, Giertz, Inderbitzin, Levine, Brocklehurst

1972-1974

Feinberg, Giertz, Inderbitzin, Levine, Brocklehurst, Glazer, Diamant, Macher

1974-1976

Giertz, Diamant, Macher, Rorsman, Berrens, Lichtenstein, Roitt

1976-1978
Rorsman, Berrens, Lichtenstein, Roitt, Austen, Parker, Rother

1978-1980

Austen, Parker, Rother, Gleich, Oronsky, Pepys, Brocklehurst, Aas

1980-1982

Gleich, Oronsky, Pepys, Brocklehurst, Aas, Sehon, Lichtenstein, Ricci

2008-2010

M Akdis, Dahlen, Saito, Stevens, Marshall,Thomas, van Ree

2012-2014

Behrendt, Befus, van Hage, Weller, Durham, Izuhara, Simon, Breiteneder

2016-2018

Bleecker, Bohle, Castells, Creticos, Levi-Schaffer, Nilsson, Pawankar, Triggiani
1982-1984

Lichtenstein, Ricci, Bach, Kishimoto, Lessof, Radermecker, Salvaggio,

Schmutzler

1984-1986

Bach, Kishimoto, Lessof, Radermecker, Salvaggio, Schmutzler, Norman, Capron

1986-1988

Norman, Schmutzler, Lessof, Salvaggio, Miyamato, Bienenstock, Ring, Marone

1988-1990

Miyamoto, Ring, Marone, Frick, Holgate, Koda, Lichtenstein, Loewenstein

1990-1992

Frick, Holgate, Koda, Loewenstein, Bousquet, Bjorksten, Romagnani, Sheffer

1992-1994

Bousquet, Bjorksten, Holgate, Romagnani, Sheffer, Behrendt, Likura, Kraft 1994-1996

Behrendt, Iikura, Kraft, Capron, Galli, Johansson, Lee, Marone

1996-1998

Capron, Denburg, Galli, Holt, Ishikawa, Johansson, Lee, Marone

1998-2000

Blaser, Denburg, Holt, Ishikawa, Kay, Platts-Mills, Togias, Vercelli

2000-2002

Blaser, Kay, Mekori, Platts-Mills,Thomas, Togias, Tomioka, Vercelli

2002-2004

Aalberse, Blaser, Bieber, Durham, Mekori, McDonald, Tomioka, Thomas

2004-2006

Aalberse, Bieber, Durham, McDonald, Holgate, Nakagawa, Levi-Schaffer, Valenta

2006-2008

Holgate, Saito, Levi-Schaffer, Valenta, Dahlen, Akdis, Marshall, Stevens, vanRee

2010-2012

Befus, Behrendt, Breiteneder, Durham,

Izuhara, Simon, van Hage, Weller

2014-2016

Castells, Creticos, Nilsson, Bleecker, Pawankar, Triggiani, Bohle, LeviSchaffer

2018-2020

Bohle, Canonica, Dahlen, Gordon, Meyers, Nadeau, Pawankar, Poulsen

CIA, Collegium Internationale Allergologicum.

The list of members of the Collegium reads like a "Who is Who" in Allergy and Clinical Immunology over the decades. Table 2 shows the list of officers. From the beginning until recently, it was predominantly the task of the secretaries to organize continuity, starting with Paul Kal- los who did this over almost 20 years followed by Alain de Weck, John Bienenstock, and Johannes Ring. A more regular election of officers was introduced in 2002 starting officer work with secretary and moving progressively on to vice president ("president elect") and finally president. 


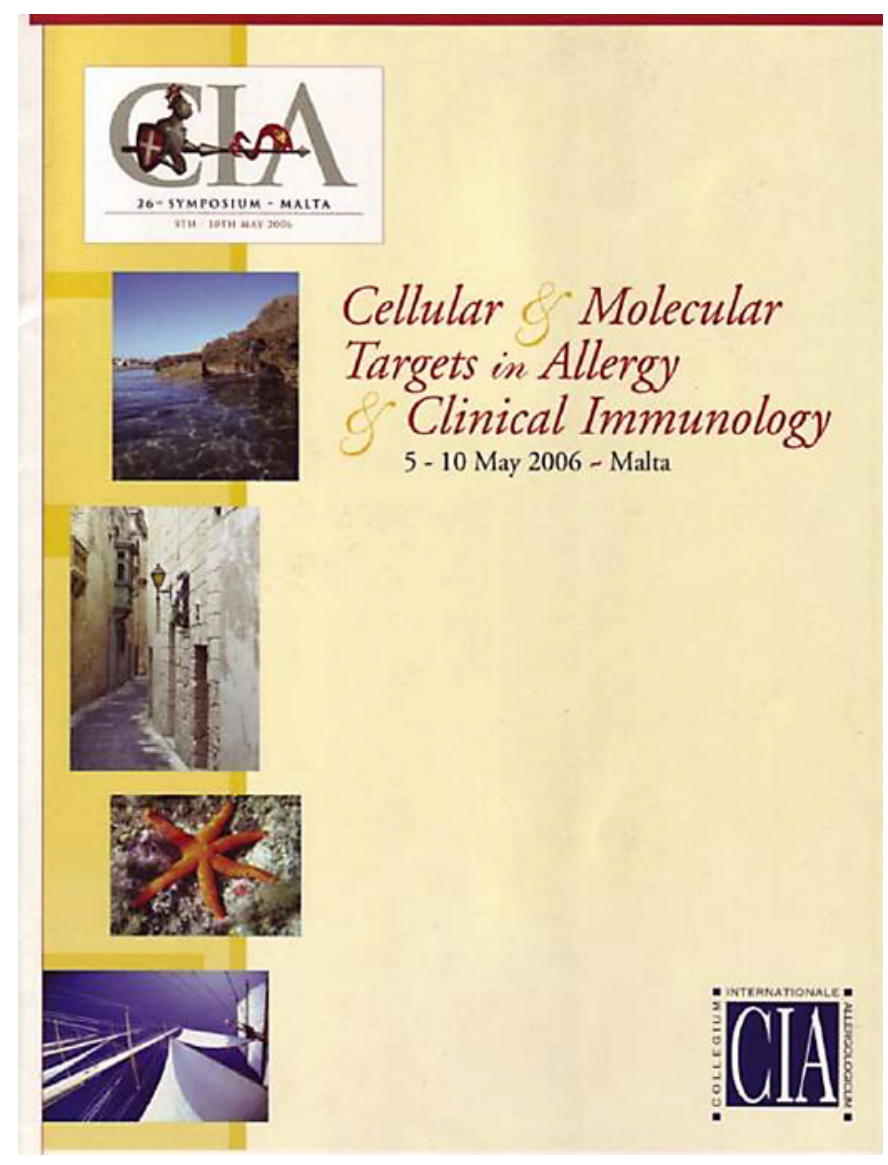

Fig. 4. Cover page of the symposium in Malta 2006 organized by S. Holgate, B. Kay, J. Ring, and G. Marone.

In the Council, the international character of the Collegium over the years is very well represented (Table 3 ). The council proposes the officers to the general assembly during the business meeting. It is also responsible for putting together the program of the symposia which is distilled from active contributions by the members critically reviewed before acceptance."This is a society which does not have politics involved in its administrative discussions, which in itself is a pleasure and a rarity!" said former president John Bienenstock.

\section{Symposia}

The biannual symposia are the major activity of the Collegium and organized in special locations preferably on attractive and sometimes isolated locations like an island in order to keep the people together after the sessions and allow free time for discussion and friendly in-
Table 4. Locations of CIA Symposia and organizers

\begin{tabular}{|c|c|c|}
\hline Date & Site & Organizer(s) \\
\hline 1954 & London & P. Kallòs, D. Harley \\
\hline 1955 & Basel & A. Stoll, E. Rothlin \\
\hline 1957 & London & P. Kallós, R.R.A. Coombs \\
\hline 1959 & Rome & L. Businco \\
\hline 1962 & Freiburg i. Br. & F. Hahn, H. Giertz, W. Schmutzler \\
\hline 1964 & London & G.B. West \\
\hline 1968 & Tel Aviv & I. Glazer, M. Feldmann \\
\hline 1970 & Montreux & A. de Weck \\
\hline 1972 & London & F. Feinberg, J. Pepys, J.L. Turk, G.B. West \\
\hline 1974 & Copenhagen & B. Diamant, N. Hjorth, P. Kallós, H. Rorsmann \\
\hline 1976 & Heidelberg & K. Rother, H. Giertz, E. Schöpf, G. Till \\
\hline 1978 & New Orleans & J. Salvaggio \\
\hline 1980 & Konstanz & P. Dukor, A. de Weck \\
\hline 1982 & Sorrento & G. Marone, M. Condorelli, G. Rossi, M. Ricci \\
\hline 1984 & $\begin{array}{l}\text { Puerto Vallarta } \\
\text { (Mexico) }\end{array}$ & P. Norman, L. Lichtenstein, T. \& K. Ishizaka \\
\hline 1986 & Göteborg & L.A. Hanson, N. Lindholm \\
\hline 1988 & Martinique & M. \& A. Capron \\
\hline 1990 & Madeira & S. Holgate, J. Bienenstock \\
\hline 1992 & Capri & G. Marone \\
\hline 1994 & Nantucket & S.J. Galli, A.L. Sheffer \\
\hline 1996 & Fuschl/Salzburg & D. Kraft, J. Ring \\
\hline 1998 & Corfu & A. Togias, L. Lichtenstein \\
\hline 2000 & Hakone & T. Ishikawa, T. Miyamoto, H. Tomioka \\
\hline 2002 & Bermuda & A. Togias, J. Bienenstock \\
\hline 2004 & Bornholm & H. Loewenstein, J. Ring \\
\hline 2006 & Malta & S. Holgate, B. Kay, J. Ring, G. Marone \\
\hline 2008 & Curacao & R. van Ree, J. Ring \\
\hline 2010 & Ischia & G. Marone, M. Triggiani \\
\hline 2012 & Jeja & Y.Y. Kim, S. Galli \\
\hline 2014 & Petersberg/Bonn & M. Maurer, H. Behrendt, S. Galli \\
\hline 2016 & Charleston & P. Creticos, B. Bochner \\
\hline 2018 & Palma de Mallorca & M. Castells, S. Holgate \\
\hline
\end{tabular}

CIA, Collegium Internationale Allergologicum.

terchange (Fig. 3-6). It is expected that the participants stay over the whole length of the 5-day symposium. A fundamental is a short boat ride which sometimes can lead to very untoward sensations like motion sickness as has happened sometimes. Table 4 shows the list and locations of the 32 symposia in the past together with the local organizers (Fig. 7-9). As previously mentioned, the 2020 meeting was planned to be held in Montebello, ON, Canada. The history of the scientific contributions to the CIA symposia reflects the progress in the field from very basic biology and immunology to the clinical aspects of allergen-specific immunotherapy, new pharmacotherapies, and novel biological therapies [3-10].

Sometimes the developments were presented by persons who later received the Nobel Prize (e.g., Bengt Sam- 


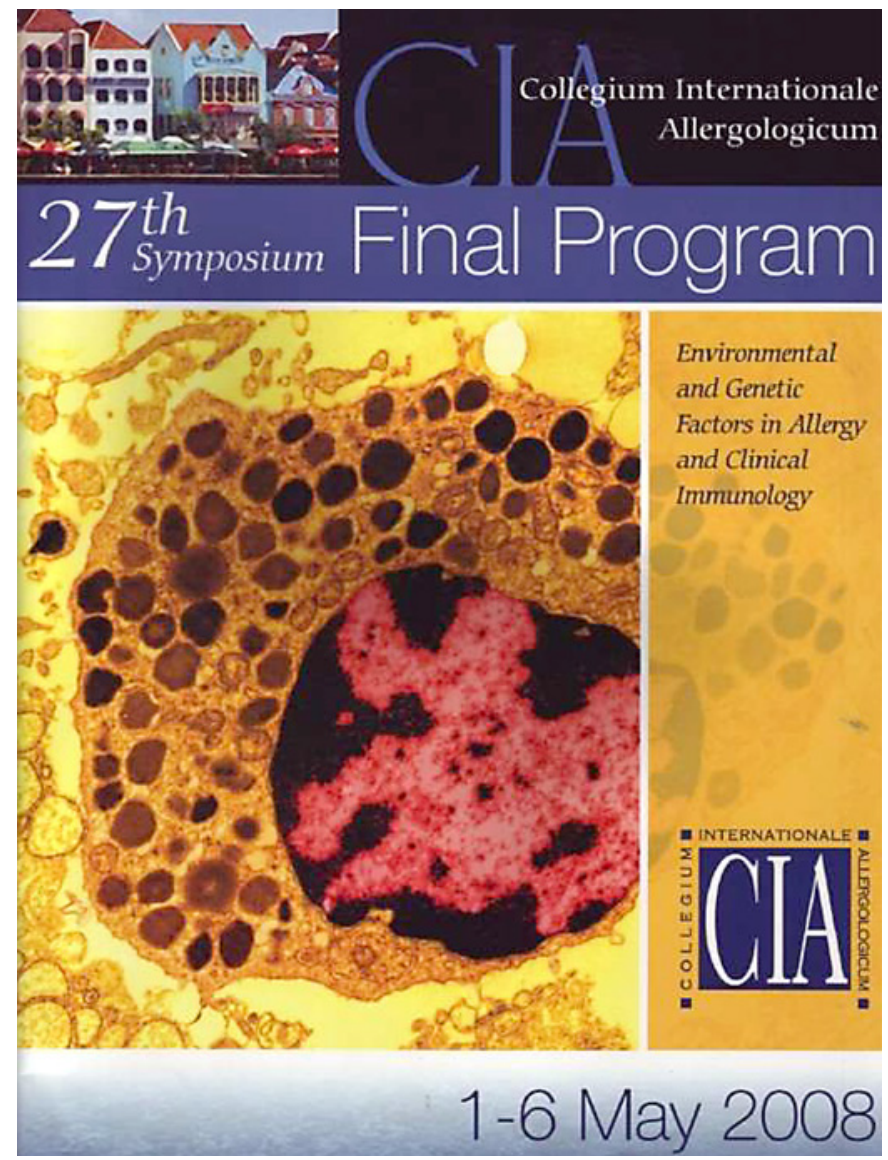

Fig. 5. Cover page of the symposium in Curacao 2008 organized by R. van Ree and J. Ring.

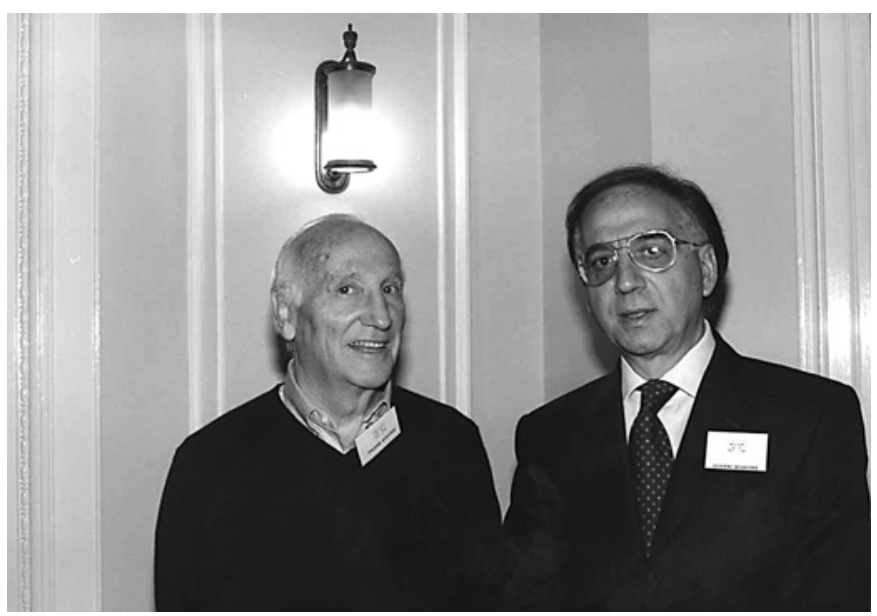

Fig. 7. Frank Austen and Gianni Marone in Capri 1992.
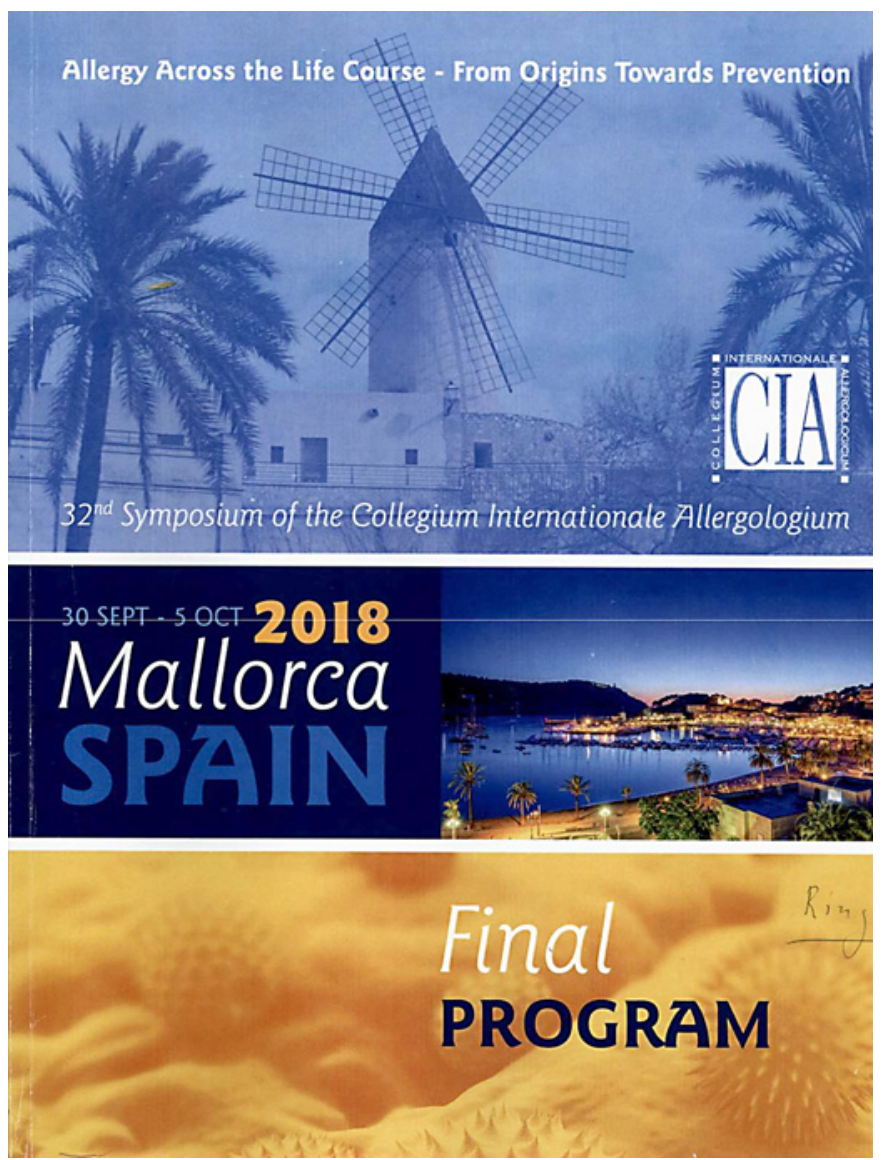

Fig. 6. Cover page of the symposium in Palma de Mallorca 2018 organized by M. Castells and S. Holgate.

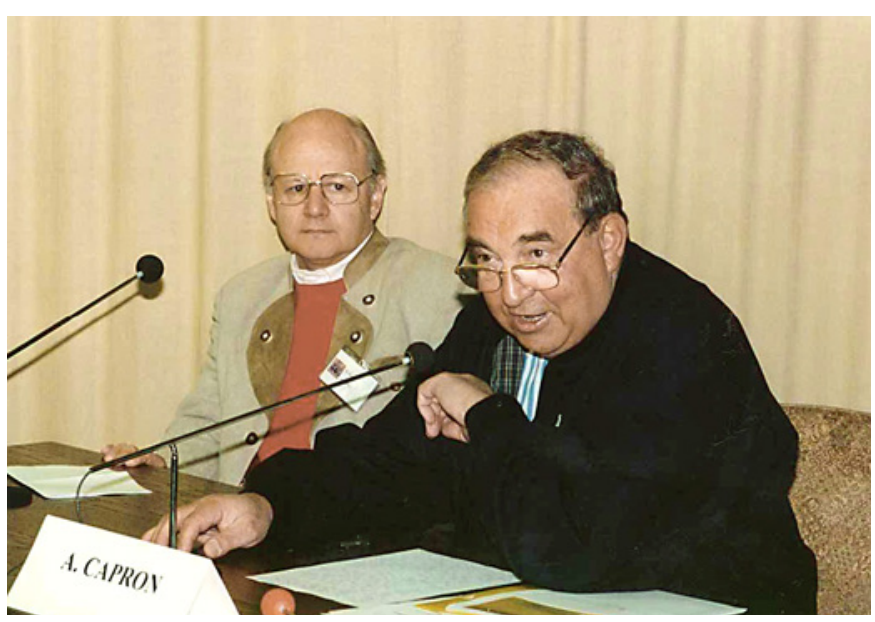

Fig. 8. Dietrich Kraft and André Capron in Fuschl 1996. 
Table 5. Carl prausnitz lectures

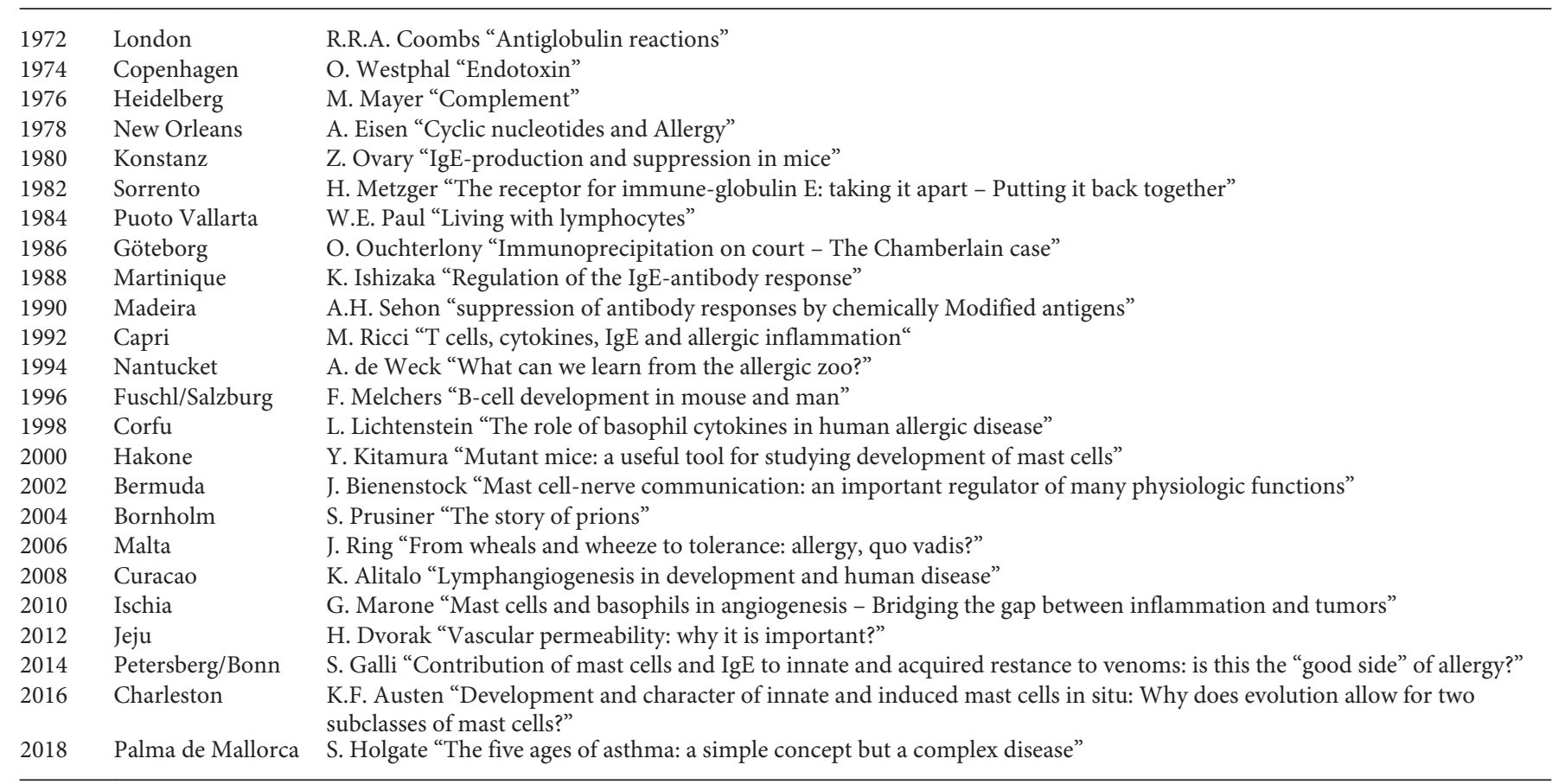

Table 6. Paul Kallós Lectures

\begin{tabular}{|c|c|c|}
\hline 1990 & Madeira & Klaus Rother (Heidelberg) "Complement in inflammation: induction of nephritides and progress to chronicity" \\
\hline 1992 & Capri & Tadamitsu Kishimoto (Japan) "Interleukin- 6 and its receptor: from cloning to clinic" \\
\hline 1994 & Nantucket & K. Frank Austen (Boston) "From slow-reacting substance of anaphylaxis to leukotriene C4 synthase" \\
\hline 1996 & Fuschl/Salzburg & $\begin{array}{l}\text { Stephen J. Galli (Boston) "Mast cell cytokine production: new insights into differential Regulation and biological } \\
\text { significance" }\end{array}$ \\
\hline 1998 & Corfu & Dietrich Kraft (Vienna) "The importance of recombinant allergens for diagnosis and therapy of IgE-mediated diseases" \\
\hline 2000 & Hakone (japan) & André Capron (Lille) "Allergy and immunity to helminths: common mechanisms or divergent pathways?" \\
\hline 2002 & Bermuda & Jan de Vries (Vienna) "Inhibition of allergic inflammation by a low molecular weight dendritic cell modulator" \\
\hline 2004 & Bornholm & Hermann Waldmann (Oxford) "Reprogramming the immune system" \\
\hline 2006 & Malta & Sir Ravindar Maini (UK) "Identification of TNF as a therapeutic target" \\
\hline 2008 & Curacao & Irving Weissmann "Normal and neoplastics stem cells cancelled J. Ring "History of Collegium Int. Allergologicum \\
\hline 2010 & Ischia & Alberto Mantovani "Inflammation - the seventh hallmark of cancer" \\
\hline 2012 & Jeju & E. Unanue "The unsolved mysteries of antigens presentation" \\
\hline 2014 & Petersburg/Bonn & B. Beutler "Genetic analysis of immune responses" \\
\hline 2016 & Charleston & L. Glimsher "ER stress in immunity and disease" \\
\hline 2018 & Palma de Mallorca & $\begin{array}{l}\text { F. Powie "Immune pathways in the intestine in health and disease" cancelled J. Ring "Reflections on the history and life of } \\
\text { CIA" }\end{array}$ \\
\hline
\end{tabular}

CIA, Collegium Internationale Allergologicum.

uelsson [Stockholm], Erwin Neher [Goettingen] or Stanley Prusiner [San Francisco], Luc Montagnier [Paris], and Bruce Beutler [Dallas]). The essence of this meeting is a very open discussion which usually stays friendly, but sometimes can be quite vehement as for instance 1986 in Goeteborg with Luc Montagnier and Roberto Gallo discussing HIV infection and in 1980 in Konstanz with the discussion between Jacques Benveniste (Paris) and Neil Pinckard (Denver) on the structure of Platelet Activating Factor.

The scientific contents of the symposia are published in proceedings volumes which for a long time were printed within the series "Monographs in Allergy" [9], then the "International Archives of Allergy and Immunology," 
Table 7. "Relaxing Lectures" (from Immunology)

1996 Fuschl/Salzburg

Carl Djerassi (San Francisco) "My life as a scientist and a writer"

1998 Corfu

Peter Jones (Newcastle, UK) "What you always wanted to know about the ancient Greeks but never dared to ask"

2000 Hakone, Japan

Tomio Tada (Tokyo) "Japanese culture and tradition: as seen through a biologist's eyes (the ma and the kata)

2002 Bermuda

David Foot "The world of demographics and the demographics of the world"

2004 Bornholm

Uffe Ellermann-Jensen (Copenhagen) “The Baltic region.

History, present and future"

2006 Malta

C. Savona-Venturea (Malta) "History of medicine in Malta"

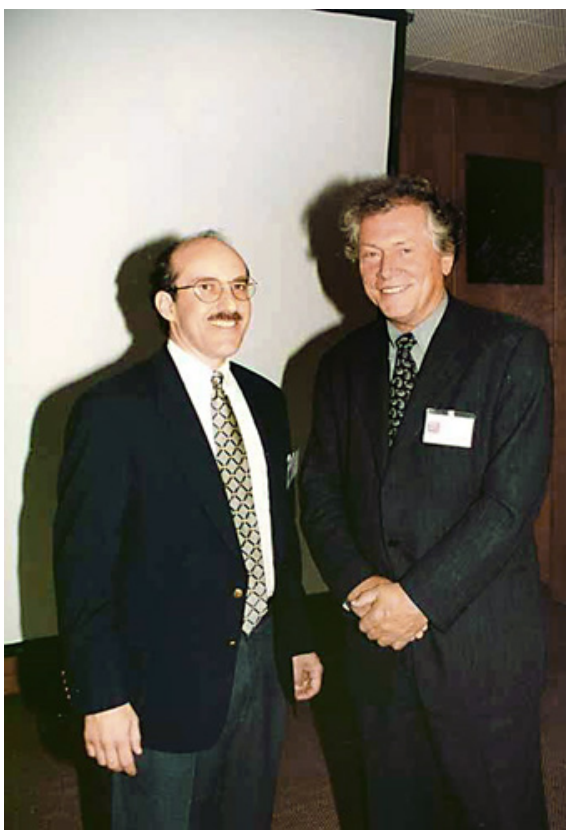

Fig. 9. Stephen Galli and Fritz Melchers in Fuschl 1996.

which is still the official journal of the Collegium [6]. Later they were printed by Hogrefe-Huber (Toronto) and Pacini editore (Pisa) $[4,7,8,10]$. In the time of internet and electronic publications, it remains open as to how long bound volumes of symposium proceedings will still be attractive. The organization of a CIA symposium is a
2008 Curacao

F. Zufall (Homburg) "Immunology, Olfaction and behavior"

2010 Ischia

E. Rietschel (Borstel) "Deadly Germs and great music"

2012 Jeju South Korea

Brenda Maddox (Wales) "The dark lady of DNA"

2014 Petersberg/Bonn

Wilhelm Barthlott (Bonn) “The secret of sacred lotus: Learning from biological surfaces"

2016 Charleston, South Carolina USA

Tom Johnson (Charleston) Magnolia gardens and the effort to preserve older azaleas and camelia varieties

2018 Palma de Mallorca

A. Vea "The great Majoricans: Lull the computer science founder, Serra a saint founder of the californias; and the Internet of things that matter"

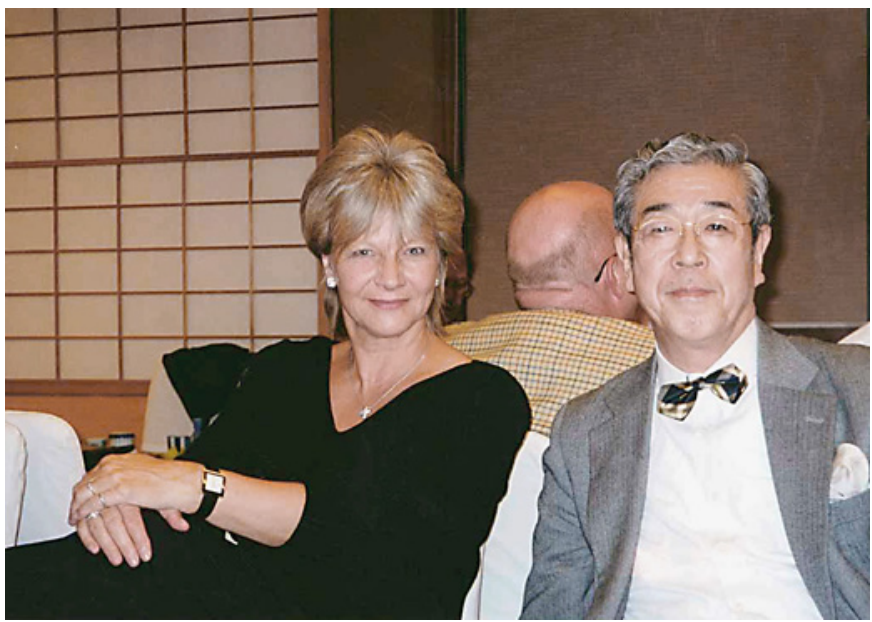

Fig. 10. Heidrun Behrendt and Tomio Tada in Hakone 2000.

major task, not so much because of the scientific content which is usually excellent since everybody tries to bring her/his best scientific results but in providing a social atmosphere of a "family spirit" also attractive for spouses, partners, and families.

From the beginning, the Collegium has been a blend of well-established scientists and young promising fellows in the field of Allergy and Clinical Immunology. The Alain de Weck travel grant program has been very successful to identify young brilliant clinical and basic investigators and to attract them into the club. 


\section{Special Lectures and Other Traditions}

All contributions submitted by the participants are regarded equal after review and acceptance and presented as oral communications or posters whereby the poster presentations have the advantage to be presented over the whole duration of the symposium, while the oral communications usually only have a time slot of 15-20 min. There are 3 special lectures which have been developed over the decades, namely Carl Prausnitz lecture (Table 5) and the Paul Kallos lecture (Table 6) dedicated to progress in allergy and immunology; the Carl Prausnitz lecture every other year is given by the departing president. Since some years the tradition of a "relaxing from immunology," lecture has been created and very much estimated to make participants not only think in a narrow-minded fashion of their own specialty but also open to other horizons and philosophical themes, as, for example, the unforgettable lecture of Tomio Tada on "The Ma and the Kata" in Hakone, Japan in 2000 (Fig. 10; Table 7).
There is a long-lasting tradition of the "CIA minutes" to give by a gifted speaker during the gala dinner and reflecting not only the scientific highlights of the preceding symposium. This tradition was started by Geoffrey West and continued by John Bienenstock and Steve Galli [2].

There also was a tradition that new members were asked interesting and sometimes quite personal questions prior to their official introduction into the Collegium at the gala dinner. Some members felt that this was the most difficult examination they had to pass in their occupational life. But all survived and are working together in this "humble and friendly spirit" so that the Collegium will have a bright future.

\section{Conflict of Interest Statement}

The authors have no conflicts of interest to declare.

\section{References}

1 Bergmann KC, Ring J, editors. History of allergy. Basel: Karger; 2014.

2 Ring J, De Weck A, editors. CIA - Collegium Internationale Allergologicum devoted to allergy research 1954-2006. 2nd ed. Munich: Urban \& Vogel; 2006.

3 Bienenstock J, Ring J, Togias A, editors. Allergy frontiers and futures. Allergy Clin Immunol Int. 2014;(Suppl 1).

4 Bochner B, Creticos P, editors. Towards precision diagnosis and targeted intervention in allergic disease. Pisa: Pacini Editore; 2018.
5 Harley D, Kallos P, editors. Aspects of allergy research. Int Arch Allergy Appl Immunol. 1955.

6 Kraft D, Grubeck-Loebenstein B, Wick G, Ring J, editors. Allergy: a disease of modern society. Int Arch Allergy Immunol. 1997;113.

7 Marone G, Triggiani M, Genovese A, editors. Translational science: from basic to clinical immunology and allergy. Pisa: Pacini Editore; 2012.
8 Maurer M, Behrendt H, Galli S, editors. Allergies: current challenges and solutions. Pisa: Pacini Editore; 2016.

9 Rother KO, De Weck A, editors. Monographs in allergy. In: Mediators of immediate type inflammatory reactions. Basel: Karger; 1977. Vol. 12.

10 van Ree R, Ring J, editors. Environmental and genetic factors in allergy and clinical immunology. Pisa: Pacini Editore; 2010. 